\title{
Ribosomal protein gene-based phylogeny for finer differentiation and classification of phytoplasmas
}

Correspondence

I.-M. Lee

leeim@ba.ars.usda.gov

\author{
M. Martini, ${ }^{1,2}$ I.-M. Lee, ${ }^{2}$ K. D. Bottner, ${ }^{2}$ Y. Zhao, ${ }^{2}$ S. Botti, ${ }^{3}$ A. Bertaccini, ${ }^{3}$ \\ N. A. Harrison, ${ }^{4}$ L. Carraro, ${ }^{1}$ C. Marcone, ${ }^{5}$ A. J. Khan $^{6}$ and R. Osler ${ }^{1}$ \\ ${ }^{1}$ Dipartimento di Biologia Applicata alla Difesa delle Piante, University of Udine, 33100 Udine, Italy \\ ${ }^{2}$ Molecular Plant Pathology Laboratory, USDA, ARS, Beltsville, MD 20705, USA \\ ${ }^{3}$ Dipartimento di Scienze e Tecnologie Agroalimentari, University of Bologna, 40127 Bologna, Italy \\ ${ }^{4}$ FLREC, University of Florida, Fort Lauderdale, FL, USA \\ ${ }^{5}$ Dipartimento di Scienze Farmaceutiche, University of Salerno, I-84084 Fisciano, Italy \\ ${ }^{6}$ Department of Crop Science, College of Agricultural and Marine Sciences, Sultan Qaboos \\ University, Al-Khod 123, Oman
}

\section{INTRODUCTION}

The highly conserved 16S rRNA gene is the most widely used gene for phylogenetic studies of prokaryotes. Phylogenetic relationships established on the basis of this gene provide a basis for modern prokaryote taxonomy. The 16S rRNA gene sequence has been used as the primary

\section{Abbreviations: $\mathrm{NJ}$, neighbour-joining; rp, ribosomal protein.}

The GenBank/EMBL/DDBJ accession numbers for the sequences determined in this study are given in Fig. 1.

Figures presenting the position of the degenerate primers and the analysis of putative restriction sites in ribosomal protein operon sequences are available as supplementary material with the online version of this paper. phylogenetic parameter for differentiation and classification of phytoplasmas in the recently emerging phytoplasma taxonomy (Lee et al., 1993b, 1998; Schneider et al., 1995; Seemüller et al., 1994, 1998). Based on extensive RFLP or phylogenetic analysis of $16 \mathrm{~S}$ rRNA gene sequences from a wide array of phytoplasma strains, 18 RFLP groups and more than 20 distinct phylogenetic groups have been identified to date (Arocha et al., 2005; Lee et al., 2000, 2006b; Seemüller et al., 1998). Each RFLP or phylogenetic group was proposed to represent at least one phytoplasma species (Gundersen et al., 1994; Seemüller et al., 1998). A consensus for naming novel phytoplasmas was reached and recommended by the IRPCM Phytoplasma/Spiroplasma Working Team - Phytoplasma Taxonomy Group (2004) that 'a 'Candidatus (Ca.) Phytoplasma' species description should refer to a single, unique $16 \mathrm{~S}$ rRNA gene sequence 
$(>1200 \mathrm{bp})^{\text {', }}$ and 'a strain can be recognized as a novel ' $\mathrm{Ca}$. Phytoplasma' species if its $16 \mathrm{~S}$ rRNA gene sequence has $<97.5 \%$ similarity to that of any previously described ' $\mathrm{Ca}$. Phytoplasma' species'. So far, 26 members of ' $\mathrm{Ca}$. Phytoplasma' have been proposed (Arocha et al., 2005; IRPCM Phytoplasma/Spiroplasma Working Team Phytoplasma Taxonomy Group, 2004; Lee et al., 2006b; Schneider et al., 2005; Valiunas et al., 2006). Because of the highly conserved nature of the 16S rRNA gene, many biologically or ecologically distinct phytoplasma strains, each of which may warrant designation of a new taxon but may fail to meet the requirement of sharing $<97.5 \%$ sequence similarity with existing ' $\mathrm{Ca}$. Phytoplasma', cannot be readily differentiated and classified. Additional unique biological properties such as insect vectors and plant hosts as well as other molecular criteria need to be included for speciation. For finer differentiation of phytoplasmas, additional phylogenetic markers such as ribosomal protein (rp) genes, secY, tuf and 23S rRNA genes and the 16S-23S rRNA intergenic spacer region sequences have been used as supplementary tools. The rp and $\sec Y$ genes are the most variable among the five markers and have proved to be useful for finer differentiation of phytoplasma strains. Gundersen et al. (1996), Lee et al. (1998, 2004a, b, 2006a) and Martini et al. (2002) noted that finer subgroup delineation within the aster yellows (16SrI), X-disease (16SrIII) and elm yellows (16SrV) groups could be achieved by combining RFLP analyses of $16 \mathrm{~S}$ rRNA and rp or $\sec Y$ gene sequences. Analysis of rp or $\sec Y$ gene sequences delineated biologically and/or ecologically distinct strains that often cannot be readily resolved by the $16 \mathrm{~S}$ rRNA gene alone.

Because of the current inability to culture phytoplasmas and the resulting lack of information about their phenotypic properties, it is inevitable that the present phytoplasma taxonomy is based on phylogeny. Phylogeny based on the 16S rRNA gene is inadequate for resolving taxonomic rank at the species level. To overcome the limitations of the 16S rRNA gene and to resolve phylogenetic relationships that are more consistent with the actual organism identity, multiple genes with varying degrees of sequence conservation have been employed to introduce additional phylogenetic parameters.

Previous studies indicated that rp genes used as phylogenetic markers have finer resolving power for the differentiation of distinct phytoplasma strains in groups 16SrI and 16SrV (Lee et al., 2004a, b; Martini et al., 2002). The extensive phylogenetic interrelationships among strains in the majority of phytoplasma groups based on rp or $\sec Y$ genes have not been established. In the present study, comparative phylogenetic analyses were performed and phylogenetic trees constructed based on sequence analyses of the $16 \mathrm{~S}$ rRNA gene and two rp genes, rplV (rpl22) and $r p s C$ ( $r p s 3)$, from representative phytoplasma strains, other mollicutes and Gram-positive bacteria. The efficacy of rp genes for finer differentiation of phytoplasma strains will be evaluated.

\section{METHODS}

Phytoplasma strains and nucleic acid preparation. Representative phytoplasma strains listed in Table 1 were used in this study. Total nucleic acid or DNA was extracted using leaf midribs or other tissues from periwinkle or original hosts that were infected by representative phytoplasma strains belonging to different phytoplasma groups according to the method described by Lee et al. (1993a) and Prince et al. (1993). These representative phytoplasma strains have been previously characterized and identified by RFLP or sequence analysis of the 16S rRNA gene (Abou-Jawdah et al., 2002; Bertaccini et al., 2000; Jacobs et al., 2003; Lee et al., 1998; Marcone et al., 1997a, b, c; Schneider et al., 1997; unpublished data).

PCR, cloning and sequencing of partial phytoplasma rp operons. The rp gene operon was amplified using the primer pair rpL2F/rp(I)R1A (5'-ATGAACCCGAACGATCACCC-3'/5'-GTTCTTTTTGGCATTAACAT-3') from some of the phytoplasma strains listed in Table 1 belonging to different phytoplasma groups (LNS1, LNS2, AP15, AT, BLL, LUM, CPS, VR, PWB, CP, AshY1, EY1, FDD, NJAY, MPV, LY, PDX, PPWB, FBP, GrapeA, PnWB, LfWB and RYD) and Acholeplasma palmae $\mathrm{J} 233^{\mathrm{T}}$. The forward primer was designed on the basis of the rp gene sequences of an aster yellows phytoplasma (GenBank accession no. M74770) covering the 3' end of $r p l W$ ( $r p l 23)$, the $r p l B$ ( $r p l 2), r p s S$ (rps19), rplV (rpl22), rpsC (rps3) genes and the 5' end of $r p l P$ (rpl16). The reverse primer, $r p(\mathrm{I}) \mathrm{R} 1 \mathrm{~A}$, described previously by Lee et al. (2003), was modified from the primer rpR1 (located in the $3^{\prime}$ end of rplP gene) (Lim \& Sears, 1992). For PCR amplification, 38 cycles were conducted in an automated thermal cycler (MJ Research DNA Thermal Cycler PTC-200) with AmpliTaq Gold polymerase (Applied Biosystems). PCR was performed in mixtures containing $1 \mu \mathrm{l}$ DNA preparation, $200 \mu \mathrm{M}$ each dNTP and $0.4 \mu \mathrm{M}$ each primer. The following conditions were used: denaturation at $94{ }^{\circ} \mathrm{C}$ for $1 \mathrm{~min}$ ( $11 \mathrm{~min}$ for the first cycle to activate the polymerase), annealing for $2 \mathrm{~min}$ at $50{ }^{\circ} \mathrm{C}$ and primer extension for $3 \mathrm{~min}$ (7 min in the final cycle) at $72{ }^{\circ} \mathrm{C}$. A negative control devoid of DNA template in the reaction mixture was included in all the PCR assays. PCR products $(5 \mu \mathrm{l})$ were electrophoresed through a $1 \%$ agarose gel, stained with ethidium bromide and visualized with a UV transilluminator. The PCR with primer pair rpL2F/rp(I)R1A yielded amplicons of the expected size (about $1.7 \mathrm{~kb}$ ) covering the $3^{\prime}$ end of $r p l B$ gene and the $r p s S, r p l V$ and $r p s C$ genes from NJAY, PDX, LUM, $\mathrm{VR}, \mathrm{AshY}$ and A. palmae $\mathrm{J} 233^{\mathrm{T}}$. The amplicons were purified using the Qiaquick PCR Purification kit (Qiagen) and cloned into Escherichia coli TOP10 by using the TOPO TA cloning kit (Invitrogen) according to the manufacturers' instructions, and inserts were sequenced with an automated DNA sequencer (ABI Prism model 3730) at the Center for Biosystems Research (University of Maryland, College Park, MD, USA) using SP6 and T7 promoter primers. The sequences were aligned by using CLUSTAL version 5 and Lasergene software (DNASTAR).

Primer design. To design degenerate rp gene-based primers, the partial rp operon sequences (about $1.7 \mathrm{~kb}$ ) amplified with primer pair rpL2F/rp(I)R1A from NJAY, PDX, LUM, VR and AshY1 phytoplasma strains and A. palmae $\mathrm{J} 233^{\mathrm{T}}$ were aligned and some conserved regions common to phytoplasma strains were identified.

Three degenerate forward primers were designed based on the sequence near the $5^{\prime}$ end: rpL2F2 (5'-CTCATGGYGGWGGWGAAGG-3'); rpL2F3 (5'-WCCTTGGGGYAAAAAAGCTC-3'); and $\operatorname{rpF1C}\left(5^{\prime}\right.$-ATGGTDGGDCAYAARTTAGG- $\left.3^{\prime}\right) \quad(\mathrm{W}=\mathrm{A}+\mathrm{T}$; $\mathrm{Y}=\mathrm{C}+\mathrm{T} ; \mathrm{D}=\mathrm{A}+\mathrm{G}+\mathrm{T}$; and $\mathrm{R}=\mathrm{A}+\mathrm{G})$. The positions of the forward primers on the alignment are shown in Supplementary Fig. S1 in IJSEM Online.

The primer rpF1C was designed within a conserved portion overlapping the position where primer $\mathrm{rpF} 1$ was previously designed 
Table 1. Designations, associated diseases, origins and phytoplasma $16 \mathrm{Sr}$ and $\mathrm{rp}$ group-subgroup affiliations of representative phytoplasma strains

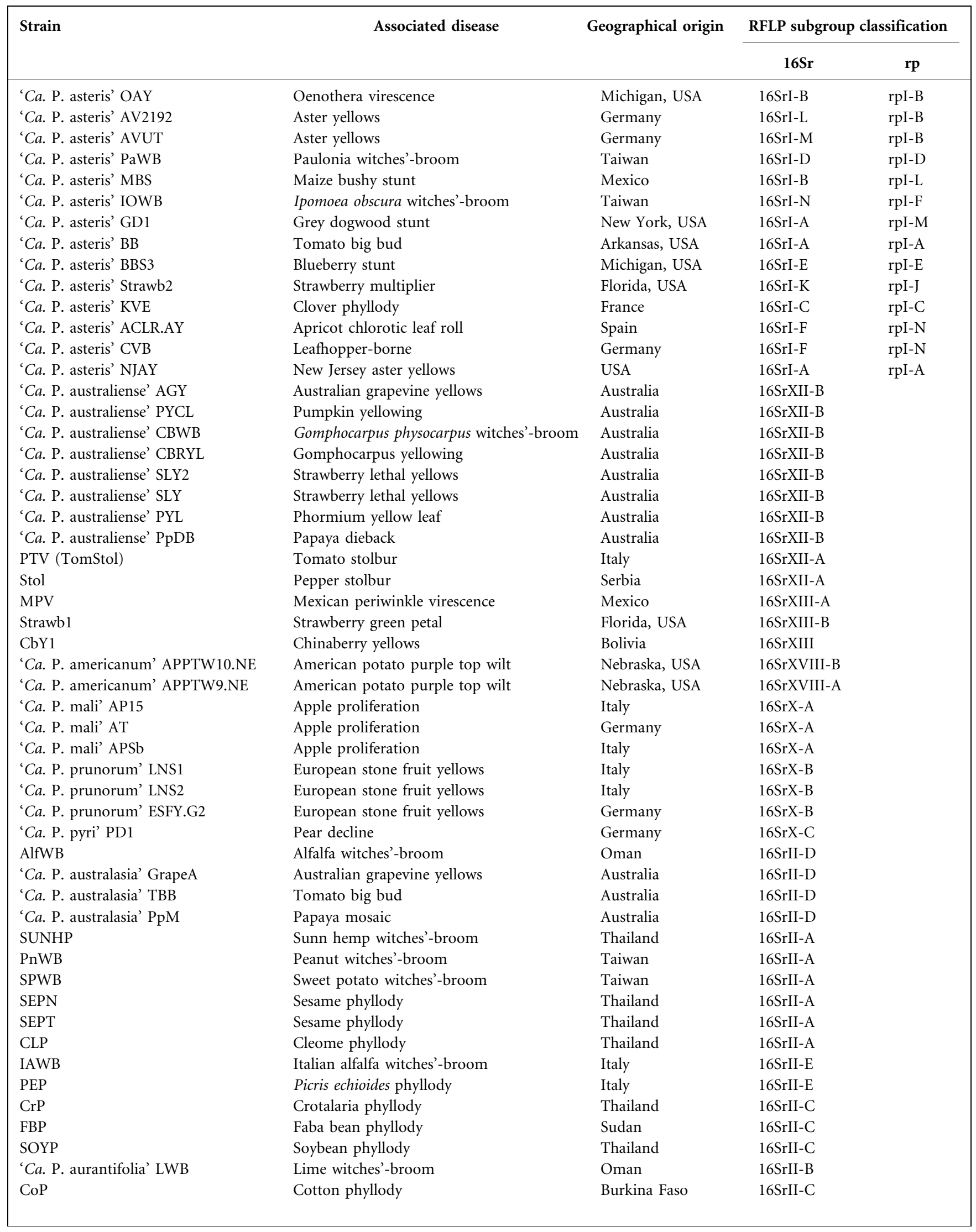


Table 1. cont.

\begin{tabular}{|c|c|c|c|c|}
\hline \multirow[t]{2}{*}{ Strain } & \multirow[t]{2}{*}{ Associated disease } & \multirow[t]{2}{*}{ Geographical origin } & \multicolumn{2}{|c|}{ RFLP subgroup classification } \\
\hline & & & $16 \mathrm{Sr}$ & $\mathbf{r p}$ \\
\hline $\mathrm{CX}$ & Peach X-disease & Canada & 16SrIII-A & rpIII-A \\
\hline WX & Peach X-disease & California, USA & 16SrIII-A & rpIII-B \\
\hline PDX & Pear decline $\mathrm{X}$-disease & California, USA & 16SrIII-A & \\
\hline CYE.L & Clover yellow edge & Lithuania & 16SrIII-B & \\
\hline WWB & Walnut witches'-broom & Georgia, USA & 16SrIII-G & rpIII-B \\
\hline JR (=PoiBI) & Poinsettia branch inducing & USA & 16SrIII-H & \\
\hline SP1 & Spirea stunt & New York, USA & 16SrIII-E & rpIII-F \\
\hline GRI & Goldenrod yellows & New York, USA & 16SrIII-D & rpIII-E \\
\hline VAC & Vaccinium witches'-broom & Germany & 16SrIII-F & \\
\hline MWI & Milkweed yellows & New York, USA & 16 SrIII-F & rpIII-D \\
\hline PBT & Pecan bunch & Georgia, USA & 16SrIII-C & rpIII-G \\
\hline PPWB & Pigeon pea witches'-broom & Florida, USA & 16SrIX-A & \\
\hline PPWBfl & Pigeon pea witches'-broom & Florida, USA & 16SrIX-A & \\
\hline PPWBja & Pigeon pea witches'-broom & Jamaica & 16SrIX-A & \\
\hline PPWBpr & Pigeon pea witches'-broom & Puerto Rico & 16SrIX-A & \\
\hline RLLfl & Rhynchosia little leaf & Florida, USA & 16SrIX & \\
\hline GLLhon & Gliricidia little leaf & Honduras & 16SrIX & \\
\hline KAP & Knautia arvensis phyllody & Italy & 16SrIX & \\
\hline PEY & Picris echioides yellows & Italy & 16SrIX & \\
\hline 'Ca. P. phoenicium' AlmWB.A112 & Almond witches'-broom & Lebanon & 16SrIX-B & \\
\hline 'Ca. P. phoenicium’ AlmWB1 & Almond witches'-broom & Lebanon & 16SrIX-B & \\
\hline CocLY.Hon & Coconut lethal yellowing & Honduras & 16 SrIV & \\
\hline LYTF.FL & Palm lethal yellowing & Florida & $16 \mathrm{SrIV}$ & \\
\hline LYF.C5 & Coconut lethal yellowing & Florida & 16SrIV-A & \\
\hline LY & Palm lethal yellowing & Florida & 16SrIV-A & \\
\hline LYmex & Coconut lethal yellowing & Mexico & $16 \mathrm{SrIV}$ & \\
\hline LYja & Coconut lethal yellowing & Jamaica & $16 \mathrm{SrIV}$ & \\
\hline LYJ.C8 & Coconut lethal yellowing & Jamaica & 16SrIV-A & \\
\hline LDY & Yucatan coconut lethal decline & Mexico & $16 \mathrm{SrIV}-\mathrm{B}$ & \\
\hline CLDO & Coconut decline & Honduras & $16 \mathrm{SrIV}$ & \\
\hline $\mathrm{CPD}$ & Coyol palm decline & Honduras & $16 \mathrm{SrIV}$ & \\
\hline CPY & Carludovica palmata leaf yellowing & Mexico & 16SrIV-D & \\
\hline 'Ca. P. trifolii' CP & Clover phyllody & Canada & 16SrVI-A & \\
\hline 'Ca. P. trifolii' PWB & Potato witches'-broom & Canada & 16SrVI-A & \\
\hline LUM & Lucerne virescence & France & 16SrVI & \\
\hline BLL & Brinjal little leaf & India & 16SrVI & \\
\hline EYIL & Illinois elm yellows & Illinois, USA & 16SrVI-C & \\
\hline VR & Vinca virescence & California, USA & 16SrVI-A & \\
\hline CPS & Catharanthus phyllody & Sudan & $16 \mathrm{SrVI}$ & \\
\hline 'Ca. P. fraxini’ AshY1 & Ash yellows & New York, USA & 16SrVII-A & \\
\hline 'Ca. P. fraxini’ AshY12 & Ash yellows & New Jersey, USA & 16SrVII-A & \\
\hline ‘Ca. P. fraxini’ AshY5 & Ash yellows & Minnesota, USA & 16SrVII-A & \\
\hline ALY882 & Alder yellows & Germany & $16 \mathrm{SrV}-\mathrm{C}$ & $\mathrm{rpV}-\mathrm{K}$ \\
\hline FD70 & Flavescence dorée & France & $16 \mathrm{SrV}-\mathrm{C}$ & $\mathrm{rpV}-\mathrm{F}$ \\
\hline FDD & Flavescence dorée & Italy & 16SrV-D & $\mathrm{rpV}-\mathrm{E}$ \\
\hline FDC & Flavescence dorée & Italy & $16 \mathrm{SrV}-\mathrm{C}$ & $\mathrm{rpV}-\mathrm{D}$ \\
\hline ALY & Alder yellows & Italy & $16 \mathrm{SrV}-\mathrm{C}$ & $\mathrm{rpV}-\mathrm{H}$ \\
\hline SpaWB229 & Spartium witches'-broom & Italy & $16 \mathrm{SrV}-\mathrm{C}$ & $\mathrm{rpV}-\mathrm{L}$ \\
\hline RuS & Rubus stunt & Italy & $16 \mathrm{SrV}-\mathrm{E}$ & $\mathrm{rpV}-\mathrm{I}$ \\
\hline HD1 & Hemp dogbane & New York, USA & $16 \mathrm{SrV}-\mathrm{C}$ & $\mathrm{rpV}-\mathrm{J}$ \\
\hline ‘Ca. P. ulmi' EY1 & Elm yellows & New York, USA & 16SrV-A & $\mathrm{rpV}-\mathrm{A}$ \\
\hline CLY5 & Cherry lethal yellows & China & $16 \mathrm{SrV}-\mathrm{B}$ & $\mathrm{rpV}-\mathrm{B}$ \\
\hline PYIn & Peach yellows & India & $16 \mathrm{SrV}-\mathrm{B}$ & $\mathrm{rpV}-\mathrm{M}$ \\
\hline 'Ca. P. ziziphi' JWB & Jujube witches'-broom & China & $16 \mathrm{SrV}-\mathrm{B}$ & $\mathrm{rpV}-\mathrm{C}$ \\
\hline
\end{tabular}


Table 1. cont.

\begin{tabular}{|c|c|c|c|c|}
\hline \multirow[t]{2}{*}{ Strain } & \multirow[t]{2}{*}{ Associated disease } & \multirow[t]{2}{*}{ Geographical origin } & \multicolumn{2}{|c|}{ RFLP subgroup classification } \\
\hline & & & $16 \mathrm{Sr}$ & rp \\
\hline RYD (In15) & Rice yellow dwarf & India & 16SrXI-A & \\
\hline SCWL & Sugar cane white leaf & Thailand & $16 \mathrm{SrXI}-\mathrm{B}$ & \\
\hline SCGS (In16) & Sugar cane grassy shoot & India & 16SrXI-B & \\
\hline
\end{tabular}

by Lim \& Sears (1992). Degenerate primers were then used to amplify putative rp gene sequences from phytoplasma groups of which rp gene sequences are not yet known.

Primer pairs rpL2F2/rp(I)R1A, rpL2F3/rp(I)R1A and rpF1C/rp(I)R1A were initially tested on several representative phytoplasma strains of phytoplasma groups listed in Table 1 (LNS2, AP15, AT, PD1, FBP, SUNHP, PnWB, TBB, GrapeA, IAWB, PEP, RYD, SCWL, SCGS, LfWB, MBS, VR, CP, CX, PPWB, KAP, LY, RuS, EY1, AshY1, PTV and MPV). They were also tested in nested PCR assays [direct PCR with primers $\mathrm{rpL} 2 \mathrm{~F} 2 / \mathrm{rp}(\mathrm{I}) \mathrm{R} 1 \mathrm{~A}$ or $\mathrm{rpL} 2 \mathrm{~F} 3 / \mathrm{rp}(\mathrm{I}) \mathrm{R} 1 \mathrm{~A}$ followed by nested PCR using primer pair $\mathrm{rpF} 1 \mathrm{C} / \mathrm{rp}(\mathrm{I}) \mathrm{R} 1 \mathrm{~A}]$ when there was no amplicon or when the amplicons were not of the expected size in the first PCR. The PCR conditions were the same as described above.

16Sr group-specific primers were designed based on a comprehensive alignment of phytoplasma rp gene sequences and their specificity was evaluated against 28 strains belonging to 12 groups (Table 2). For evaluation of the specificity of $\mathrm{rp}$ gene-based $16 \mathrm{Sr}$ group-specific

Table 2. Semi-universal and $16 \mathrm{Sr}$ group-specific rp-based primers designed in this and previous studies

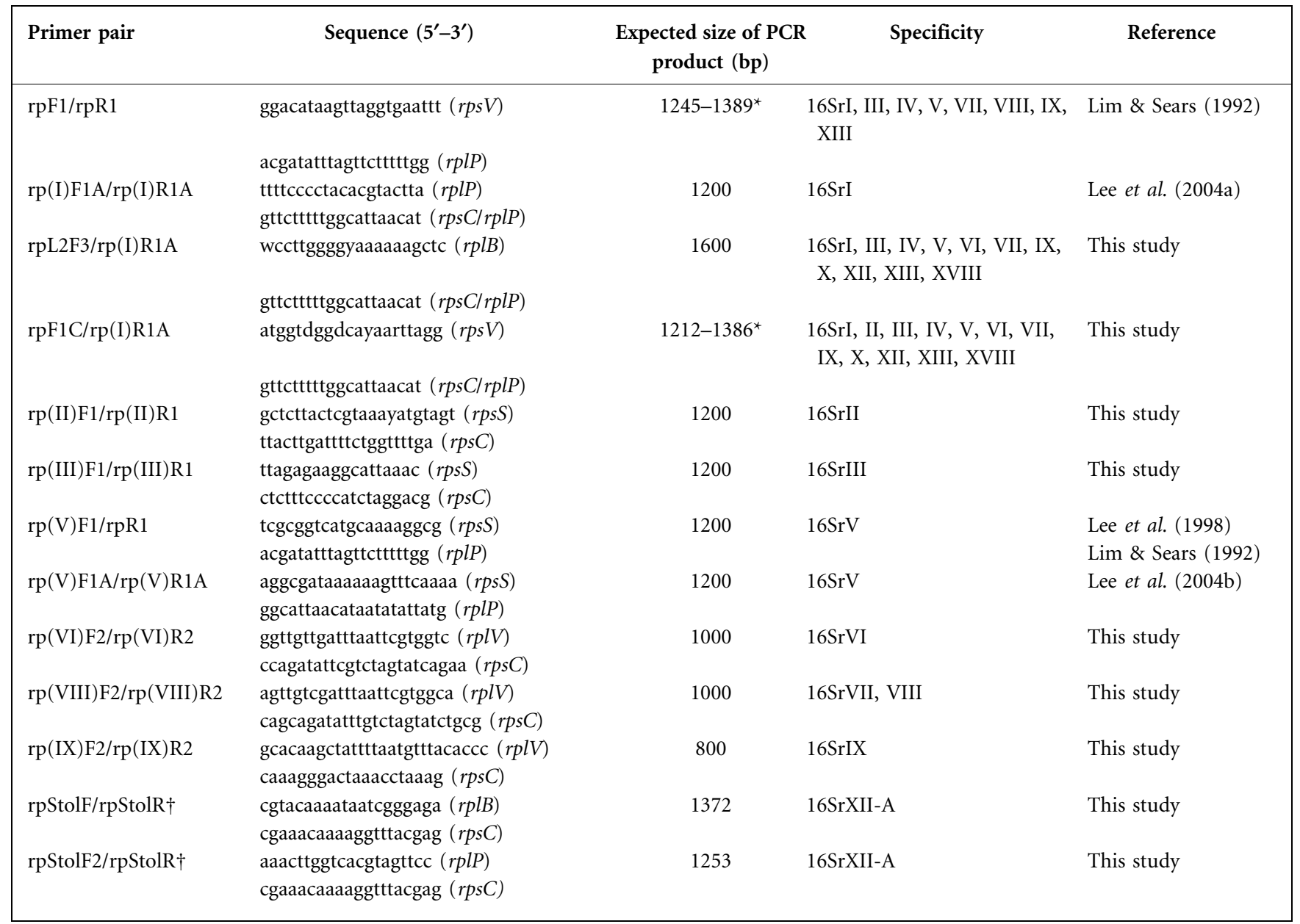

${ }^{\star}$ Product size is group-dependent.

$\dagger$ PCR conditions with primer pairs rpStolF/rpStolR and rpStolF2/rpStolR were initial denaturation at $94{ }^{\circ} \mathrm{C}$ for 2 min, $40 \mathrm{cycles}$ of $1 \mathrm{~min}$ at $94{ }^{\circ} \mathrm{C}$, $45 \mathrm{~s}$ at $53{ }^{\circ} \mathrm{C}$ and $90 \mathrm{~s}$ at $72{ }^{\circ} \mathrm{C}$ and a final extension at $72{ }^{\circ} \mathrm{C}$ for $8 \mathrm{~min}$. 
primer pairs, PCR was performed as described previously with an annealing temperature of 50 or $55^{\circ} \mathrm{C}$.

PCR amplification of rp gene operons from representative phytoplasmas. Primer pair $\mathrm{rpF} 1 \mathrm{C} / \mathrm{rp}(\mathrm{I}) \mathrm{R} 1 \mathrm{~A}$ was used to amplify rp genes from 54 representative phytoplasma strains listed in Table 1 and A. palmae $\mathrm{J}_{233^{\mathrm{T}}}$. The PCR conditions were the same as described above. The amplicons (about $1.2 \mathrm{~kb}$, containing the rplV$r p s C$ gene sequence) were purified, cloned and sequenced as described above.

PCR amplification of the 16S rRNA gene from representative phytoplasmas. Primer pair P1/P7 was used to amplify the $16 \mathrm{~S}$ rRNA gene, spacer region and $5^{\prime}$ end of the $23 \mathrm{~S}$ rRNA gene from 19 representative phytoplasma strains listed in Table 1. The PCR conditions were the same as described above with an annealing temperature of $55^{\circ} \mathrm{C}$. The PCR products from primers P1/P7 (about $1.8 \mathrm{~kb}$, containing the $16 \mathrm{~S}$ rRNA gene sequence) were purified, cloned and sequenced as described above.

Phylogenetic analysis. To determine the phylogenetic relationships among phytoplasmas, other mollicutes and closely related walled bacteria, a comprehensive analysis was performed based on nucleotide and deduced amino acid sequences of rp genes $(r p l V$ and $r p s C$ ) and on the 16S rRNA gene from representative mollicutes: 46 phytoplasmas (42 based on $16 \mathrm{~S}$ rRNA), two acholeplasmas, 10 mycoplasmas, one mesoplasma, one ureaplasma, two spiroplasmas and 28 Gram-positive walled bacterial species belonging to the Bacillales, 'Clostridia', 'Lactobacillales' and Actinobacteria. The rp nucleotide and deduced amino acid sequences for mollicutes and other Gram-positive walled bacteria used in this study were obtained mostly from complete genome sequences available in GenBank (Figs 1 and 2). Rp nucleotide and deduced amino acid sequences were aligned as described above. Each output alignment was converted to NBRF/Pir format and was trimmed using GBLOCKS (version 0.91b) to eliminate poorly aligned positions (Castresana, 2000). The trimmed alignment was converted back to MEGALIGN. Cladistic analyses were performed with PAUP, version 4.0 (Swofford, 1998), on a Power Mac G4. Uninformative characters were excluded from analyses. A phylogenetic tree was constructed by a heuristic search [or the neighbour-joining (NJ) algorithm] via random stepwise addition implementing the tree bisection and reconnection branch-swapping algorithm to find the optimal tree(s) (Gundersen et al., 1994). Among the taxa analysed, a high-G+C-content Gram-positive bacterium, Streptomyces coelicolor A3(2), was most distantly related to the phytoplasmas. This strain was designated the outgroup to root the tree. The analysis was replicated 1000 times. Bootstrapping was performed to estimate the stability and support for the inferred clades.

Phylogenetic interrelationships among 87 phytoplasma strains (Table 1) were determined based on $\mathrm{rp}$ genes (with nucleotide sequences) and among 78 phytoplasma strains (Table 1) based on the $16 \mathrm{~S}$ rRNA gene. Sequence alignment and cladistic analyses were performed as described above. Two Acholeplasma strains and Bacillus subtilis 168 were included in the analyses. B. subtilis 168 was selected as the outgroup to root the tree. Sequence similarities were calculated by using the MEGALIGN program (Lasergene software; DNASTAR).

$\mathrm{Rp}$ and 16S rRNA gene sequences of phytoplasma strains used in phylogenetic analyses were either sequenced in this work or obtained from GenBank.

Restriction maps. To evaluate the efficacy of rp genes for finer differentiation of phytoplasma strains in clover proliferation group (16SrVI) and apple proliferation group (16SrX), putative restriction maps were constructed by using the MapDraw program (Lasergene software; DNASTAR).

\section{RESULTS AND DISCUSSION}

\section{Efficacy of degenerate primer pairs for amplification of the phytoplasma rp operon}

Primer pairs rpL2F3/rp(I)R1A and rpF1C/rp(I)R1A both amplified a fragment from genomic DNA of representative phytoplasma strains belonging to the following groups: $\mathrm{AY}$ (16SrI), X-disease (16SrIII), EY (16SrV), CP (16SrVI), AshY (16SrVII), PPWB (16SrIX), AP (16SrX), Stolbur (16SrXII), MPV (16SrXIII) and APPTW (16SrXVIII) (Table 1). Representative strains of the LY group (16SrIV) were amplified in a semi-nested PCR using primer pair rpL2F3/rp(I)R1A in a first PCR followed by primer pair $\mathrm{rpF} 1 \mathrm{C} / \mathrm{rp}(\mathrm{I}) \mathrm{R} 1 \mathrm{~A}$. Rp genes from representative strains of the PnWB group (16SrII) were amplified using the primer pair $\mathrm{rpF} 1 \mathrm{C} / \mathrm{rp}(\mathrm{I}) \mathrm{R} 1 \mathrm{~A}$. They were amplified by the primer pair rpL2F2/rp(I)R1A as well, but in many cases the amplification resulted in multiple bands. Members of phytoplasma groups 16SrVIII and 16SrXI didn't yield amplicons of the expected size, probably because of a lack of primer specificity for these phytoplasma groups or degradation of the DNA templates.

\section{PCR-amplified partial rp gene operons from diverse phytoplasmas}

PCR using primer pair $\mathrm{rpF} 1 \mathrm{C} / \mathrm{rp}(\mathrm{I}) \mathrm{R} 1 \mathrm{~A}$ yielded DNA amplicons (partial rp gene operons) from many phytoplasma strains listed in Table 1. The amplicons amplified from members of phytoplasma group 16SrII ranged from 1284 to $1309 \mathrm{bp}$. The amplicons amplified from members of phytoplasma group $16 \mathrm{SrVI}$ were homogeneous in size (1266 or $1267 \mathrm{bp}$ ). Members of phytoplasma group 16SrVII yielded an amplicon of $1272 \mathrm{bp}$. Coconut lethal yellows (LY) phytoplasma strains, representative of the lethal yellows phytoplasma group (16SrIV), produced an amplicon of $1247 \mathrm{bp}$. Phytoplasma strains belonging to the pigeon pea witches'-broom (PPWB) phytoplasma group (16SrIX) yielded an amplicon of $1262 \mathrm{bp}$ in strains PEY, PPWB and KAP and an amplicon of $1239 \mathrm{bp}$ in strain AlmWB. Members of the X-disease phytoplasma group (16SrIII) yielded an amplicon of 1386 or 1387 bp from all strains except strain MW1, which yielded an amplicon of $1346 \mathrm{bp}$. Phytoplasma strains AT, PD1 and LNS2 belonging to the AP phytoplasma group (16SrX) yielded an amplicon of $1243 \mathrm{bp}$, while strains AP15 and APSb yielded amplicons that were respectively 12 and $48 \mathrm{bp}$ longer. Phytoplasmas NJAY and MBS (both 16SrI), MPV (16SrXIII), PTV (TomStol) (16SrXII) and APPTW (16SrXVIII) yielded amplicons of 1260, 1263, 1222 and 1212 bp, respectively.

\section{Congruence between the rp gene-based phylogenetic tree and the 16S rRNA gene-based tree}

Comparative cladistic analyses were performed by using $r p l V-r p s C$ and $16 \mathrm{~S}$ rRNA gene sequences from phytoplasma 
strains across 12 distinct phytoplasma $16 \mathrm{Sr}$ groups (Lee et al., 1998, 2006b), other representative mollicutes and Grampositive walled bacteria. The analyses resulted in 32 equally parsimonious trees based on rp genes and 126 trees based on the 16S rRNA gene; representative trees were selected (Fig. 1). The phylogenetic tree inferred from rp genes (Fig. 1a) had an overall topology similar to that inferred from the $16 \mathrm{~S}$ rRNA gene (Fig. 1b). The two trees showed similar major branching orders, beginning with the outgroup $S$. coelicolor A3(2) followed by the high-G $+\mathrm{C}$-content Gram-positive bacteria, low-G $+\mathrm{C}$-content Gram-positive bacteria and mollicutes. The mollicutes clade contained two distinct subclades for both the rp and 16S rRNA gene analyses. Plant-pathogenic phytoplasmas clustered with Acholeplasma strains, forming a subclade. Plant-pathogenic spiroplasmas clustered with animal- and human-pathogenic mycoplasmas, forming another subclade. The closest relatives of the mollicutes were low-G + C-content Gram-positive bacteria belonging to the 'Lactobacillales', Bacillales and 'Clostridia'. The results are generally in agreement with those reported in previous phylogenetic studies based on the 16S rRNA gene (Jung et al., 2002; Lee et al., 1998; Seemüller et al., 1998). However, the detailed branching orders in the 16S rRNA gene- and rp gene-based trees were not entirely parallel, suggesting unequal rates of change of the $16 \mathrm{~S}$ rRNA and rp genes over the course of their evolution. The rp genes have probably undergone more rapid change than the $16 \mathrm{~S}$ rRNA gene. As a result, the rp gene-based tree delineated more defined phylogenetic interrelationships among taxa, especially in the phytoplasma groups, that cannot be readily resolved by the highly conserved 16S rRNA gene-based phylogeny.

The rp gene-based phylogeny using nucleotide sequences indicated that the members of the 'Clostridia' among the low-G + C-content Gram-positive bacteria are the closest relatives of the mollicutes, followed by members of the Bacillales and 'Lactobacillales' in all 32 of the most parsimonious trees, although the stability of the branching order in this region was supported only by low $(<50 \%)$ bootstrap values, which indicated some uncertainty for the inferred character stability among these taxa. The results are in agreement with results reported in a previous study (Zhao et al., 2005). A phylogenetic tree based on deduced amino acid sequences of rp genes for these same taxa resulted in a similar branching order (data not shown).

Phylogenetic analyses using the $\mathrm{NJ}$ algorithm resulted in a tree with a topology similar to that of the heuristic tree described above when the $16 \mathrm{~S}$ rRNA gene was used for the analysis, but generated a tree with a different topology (among basal mollicute taxa) when rp genes were used for the analysis (Fig. 2a, b). In the rp NJ tree (Fig. 2a), phytoplasmas together with the two Acholeplasma strains formed a monophyletic group that is paraphyletic to the clade consisting of low-G + C-content Gram-positive bacteria in the Bacillales and 'Lactobacillales'. The other mollicutes (spiroplasmas and animal- and human-pathogenic mycoplasmas) together with the low-G + C-content Gram-positive bacteria of the 'Clostridia' formed a separate monophyletic group. The discrepancies were unexpected and resulted from very few nucleotide substitutions, as shown by the low bootstrap values in several major branches. However, overall, the nucleotide sequence similarity data were consistent with the phylogenetic relationships inferred by the branching order (data not shown). These results implied that phytoplasmas and acholeplasmas may have a small number of rp characteristics more similar to Gram-positive walled bacteria than to other mollicutes such as mycoplasmas and spiroplasmas. Recent findings (Bai et al., 2006; Oshima et al., 2004) based on characterization of phytoplasma genomes support these conclusions. Sequences of phytoplasma genes often showed the best matches with Gram-positive Bacillus strains in BLAST and FASTX searches. Miyata et al. (2002a, b) reported that the gene organization of some phytoplasma operons such as $\mathrm{S} 10-s p c$ and $s t r$ resembled that of $B$. subtilis but not those of mycoplasmas. The different codon usage in members of the class Mollicutes offers more evidence in favour of a distinct evolution of phytoplasmas and acholeplasmas from the other mollicutes. Mycoplasma, Ureaplasma, Spiroplasma and Mesoplasma species use UGA as a tryptophan codon instead of a stop codon, a feature found in vertebrate, ascidian, echinoderm, Drosophila, yeast, mould and protozoan mitochondria (Nei \& Kumar, 2000), whereas phytoplasmas and acholeplasmas use the conventional UGG codon for tryptophan and UGA as a stop codon (Razin et al., 1998).

Fig. 1. Phylogenetic trees constructed by parsimony (PAUP version 4.0b) analyses of sequences of $r p$ genes $r p / V(r p / 22)$ and rpsC (rps3) (a) and 16S rRNA genes (b) from 62 and 58 members, respectively, of the class Mollicutes, including 46 (a) and 42 (b) phytoplasma strains, and representatives of Gram-positive, high-G + C- and low-G + C-content walled bacteria, employing Streptomyces coelicolor $\mathrm{A} 3(2)$ as the outgroup. Sequences were aligned with CLUSTAL version 5 . The trees were obtained through a heuristic search algorithm. Branch lengths are proportional to the number of inferred character state transformations. Bootstrap values are shown on branches. Bars, 10 inferred character state changes. Phytoplasma strain abbreviations are defined in Table 1. Bacterial genus abbreviations: A., Acholeplasma; B., Bacillus; C., Clostridium; Cor., Corynebacterium; E., Enterococcus; Lis., Listeria; Lac., Lactobacillus; Lactoc., Lactococcus; M., Mycoplasma; Mes., Mesoplasma; Myc., Mycobacterium; O., Oceanobacillus; S., Streptomyces; Sp., Spiroplasma; Sta., Staphylococcus; Str., Streptococcus; T., Thermoanaerobacter; U., Ureaplasma. GenBank accession numbers of sequences obtained in this study are indicated in bold. The sequence of Spiroplasma kunkelii CR2-3x was accessed at http://www.genome.ou.edu/spiro.html 


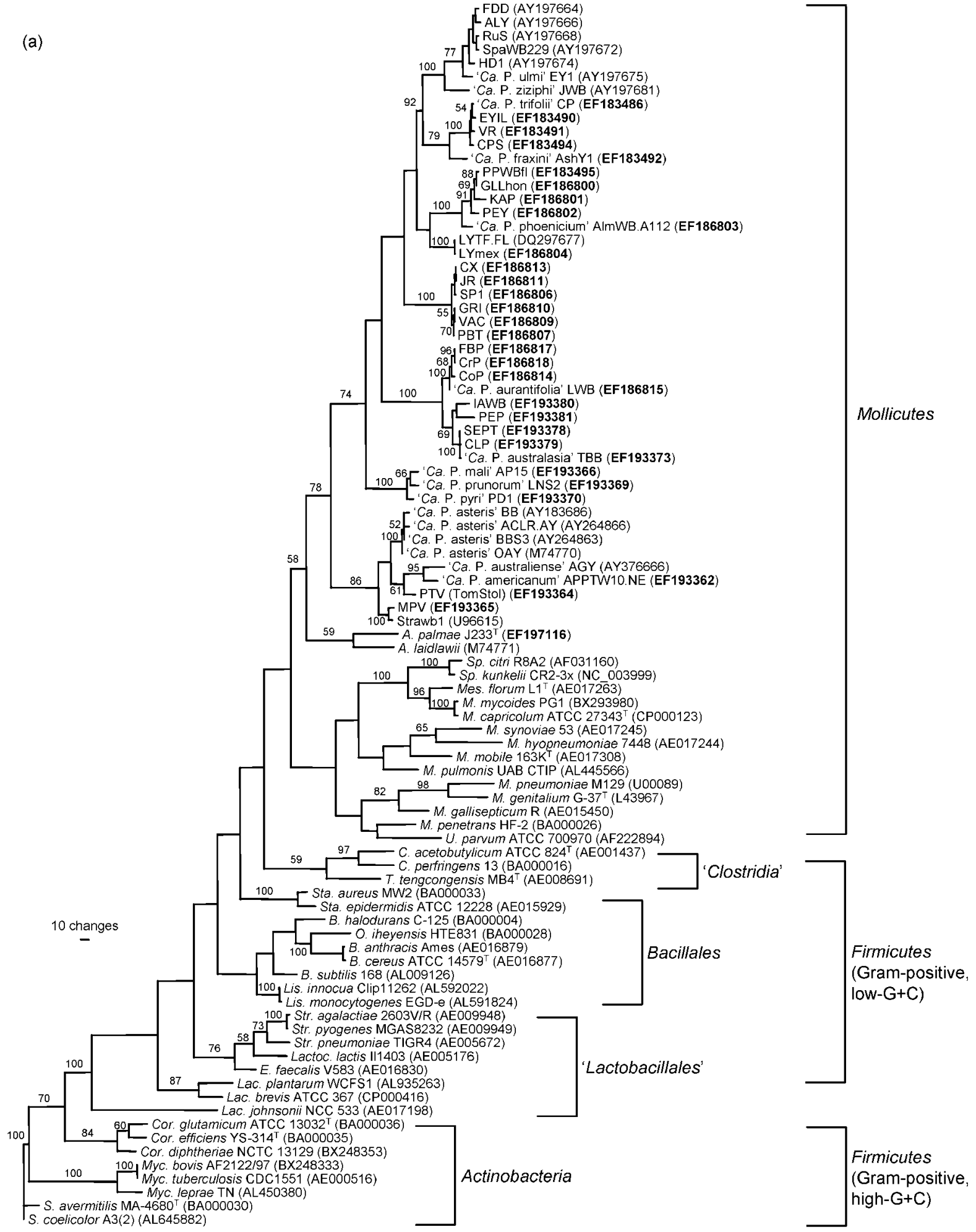

\section{Phylogenetic trees of phytoplasmas based on nucleotide sequences of $r p / V$ and $r p s C$ genes and $16 S$ rRNA gene sequences}

Phylogenetic analysis using $r p l V-r p s C$ nucleotide sequences from 87 phytoplasma strains representing 14 distinct phytoplasma groups (or $12 \mathrm{16Sr}$ groups according to Lee et al., 1998) or more than 40 subgroups, A. palmae $\mathrm{J}_{23}{ }^{\mathrm{T}}$, Acholeplasma laidlawii JA1 and B. subtilis 168 (as an outgroup) resulted in 288 equally parsimonious trees. One of the most parsimonious trees is presented in Fig. 3(a). The phylogeny inferred by $r p l V-r p s C$ sequences was nearly 


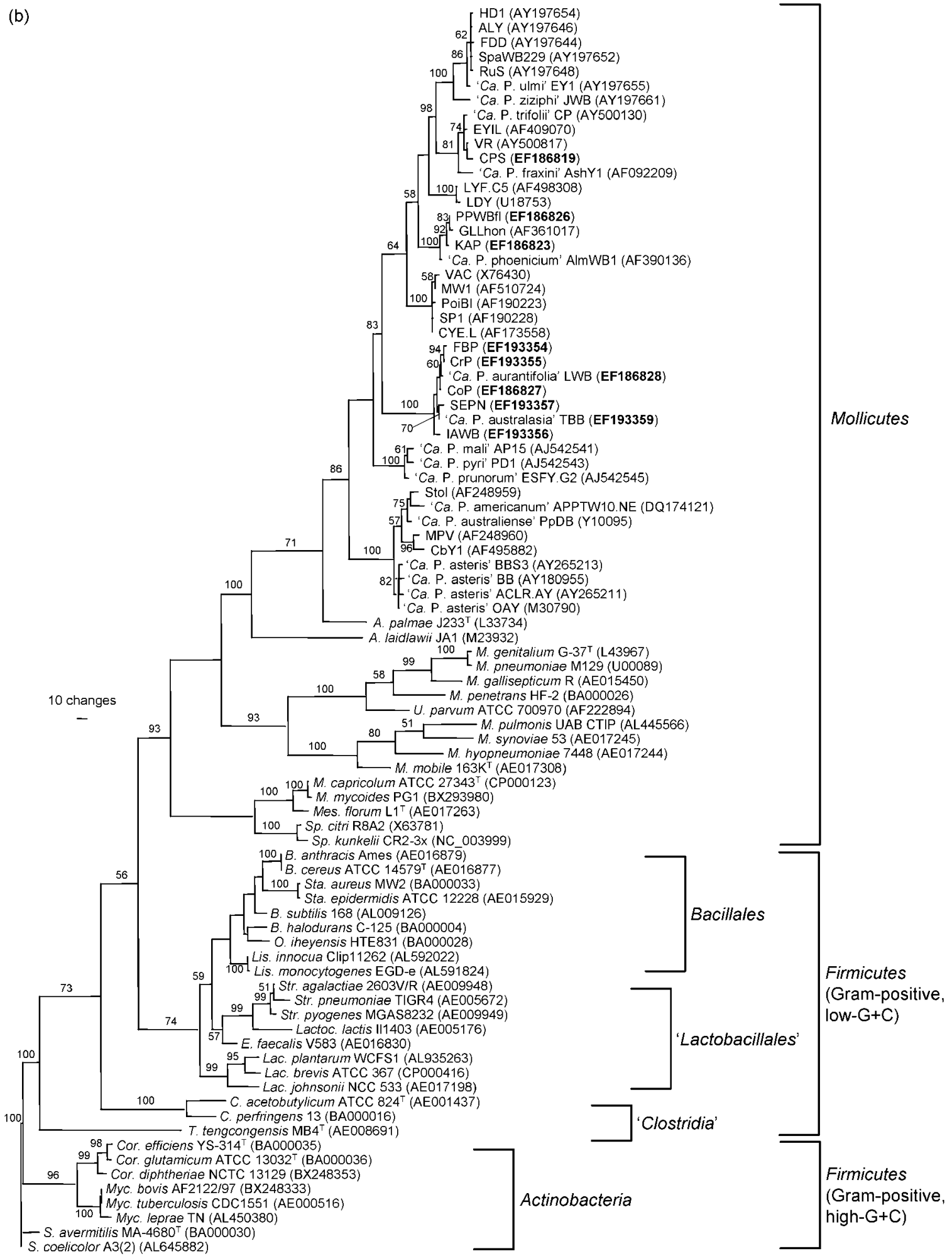

congruent with that inferred by $16 \mathrm{~S}$ rRNA gene analysis (Fig. 3b), indicating similar interrelatedness among phytoplasma taxa. This is in agreement with a previous report in which a phylogenetic study was conducted based on the $r p l V$ sequences of 11 phytoplasma strains representative of eight phytoplasma subclades (Gundersen et al., 1994).
As shown in previous phylogenetic studies based on the 16S rRNA gene (Jung et al., 2002; Lee et al., 1998, 2000; Seemüller et al., 1998), phytoplasmas formed a large monophyletic group closely related to A. palmae and A. laidlawii. In this study, both rp- and 16S rRNA gene-based trees revealed that A. palmae and A. laidlawii constituted a 
monophyletic group, paraphyletic to the phytoplasma group. On the basis of the $r p l V-r p s C$ sequences analysed, a total of 19 distinct phytoplasma monophyletic groups or taxa, which we designated subclades (using lower-case roman numerals), could be recognized based on both tree branch lengths and sequence similarities. Ten rp subclades (i, ii, iii, iv, vi, vii, viii, $i x, x$ and $x i i)$ corresponded with $16 \mathrm{~S}$ rRNA gene subclades identified by Gundersen et al. (1994), Lee et al. (1998) and Montano et al. (2001). In these studies, a total of 14 distinct $16 \mathrm{Sr}$ subclades were recognized.

The rp gene-based phylogeny clearly resolved more distinct subclades than the 16Sr RNA gene-based phylogeny (Gundersen et al., 1994). For example, the EY group $(16 \mathrm{SrV})$ was resolved into two distinct rp subclades ( $x$ and $x x$ ), the LY group (16SrIV) was resolved into two rp subclades (vii and xxiii), the PPWB group (16SrIX) was resolved into two rp subclades ( $v i$ and $x i x$ ), the PnWB group (16SrII) was resolved into four rp subclades ( $i i i$, xviii, xvii and xvi) and the stolbur (16SrXII) and American potato purple top wilt (16SrXVIII) groups were resolved into three subclades (xii, xxi and xxii). Each distinct subclade shared no more than $96 \%$ rp sequence similarity to any other subclade. The stability of the subclades was supported by high bootstrap values. We propose that each rp subclade represents at least one phytoplasma species.

\section{Genetic variations of phytoplasmas assessed by comparative sequence analyses of two different conserved genes}

The genetic variations among members of a given $16 \mathrm{Sr}$ phytoplasma group were determined based on sequences of the rp and $16 \mathrm{~S}$ rRNA genes obtained both in this work and from GenBank. Overall, the rp genes exhibited greater sequence variation than the 16S rRNA gene, confirming previous results (Gundersen et al., 1994, 1996). The average nucleic acid sequence similarity of $\mathrm{rp}$ genes among members of two different phytoplasma groups ranged from $50.4 \%$ (among members of groups 16SrXII-A and $16 \mathrm{SrII}$ ) to $83.5 \%$ (among members of groups $16 \mathrm{SrV}$ and 16SrVI), compared with $85.1 \%$ (groups 16SrIX and 16SrX) to $96.9 \%$ (groups $16 \mathrm{SrVI}$ and $16 \mathrm{SrVII}$ ) similarity for the $16 \mathrm{~S}$ rRNA gene sequences. Members of phytoplasma groups 16SrX, I, XII, XIII and XVIII are the phytoplasma strains most closely related to Acholeplasma strains, sharing an average rp gene sequence similarity of $63 \%$ with $A$. palmae $\mathrm{J} 233^{\mathrm{T}}$ and $55.8 \%$ with A. laidlawii JA1. Members of the AY (16SrI) and EY (16SrV) phytoplasma groups exhibited similar degrees of genetic variability in these two genes, showing average sequence similarities ranging from 98.4 to $99.2 \%$ and 98.6 to $99.5 \%$, respectively, based on the $16 \mathrm{~S}$ rRNA gene, and from 96.8 to $98.2 \%$ and 96.5 to $98.1 \%$, respectively, based on the rp gene sequences. Members of the CP (16SrVI), PPWB (16SrIX) and AP (16SrX) phytoplasma groups exhibited different degrees of genetic variability in these two genes. The average sequence similarity among members of the AP phytoplasma group varied from 98.7 to $99.4 \%$ based on the 16S rRNA gene and from 93.4 to $96.5 \%$ based on the rp genes. Based on the 16S rRNA gene, the average sequence similarities ranged from 98.3 to $99.4 \%$ among members of the PPWB phytoplasma group and from 98.4 to $99.2 \%$ among members of the CP phytoplasma group. However, more heterogeneity was evident in the PPWB phytoplasma group than in the CP group when rp genes were analysed. The average sequence similarities ranged from 87.8 to $96.8 \%$ among members of the PPWB phytoplasma group and from 97.8 to $98.8 \%$ among members of the $\mathrm{CP}$ phytoplasma group. The lowest average sequence similarities were shown by members of the PnWB (16SrII) phytoplasma group in both genes, ranging from 97.4 to $98.8 \%$ based on the $16 \mathrm{~S}$ rRNA gene and from 86 to $93.1 \%$ based on the rp genes.

The greater sequence variation makes the rp genes a better molecular tool for phytoplasma classification. Morevariable rp gene sequences are ideal for use in RFLP analysis for finer differentiation of ecologically or biologically distinct strains within a given $16 \mathrm{Sr}$ phytoplasma group. Genetically distinct phytoplasma strains that cannot be differentiated on the basis of the highly conserved $16 \mathrm{~S}$ rRNA gene are able to be differentiated on the basis of the less-conserved rp genes. While closely related strains shared similar high similarities $(>99 \%)$ on the basis of both $16 \mathrm{~S}$ rRNA and rp gene sequences, distinct strains, including those unresolved by $16 \mathrm{~S}$ rRNA gene sequence, between two $16 \mathrm{Sr}$ subgroups or within a subgroup manifested their variability when analysed by $r p l V$ and $r p s C$ gene sequences. For example, based on $16 \mathrm{~S}$ rRNA gene sequences, the beet leafhopper-transmitted agent (BLTVA) phytoplasma (e.g. strain VR), which causes potato purple top wilt in Oregon and Washington states (Lee et al., 2004c), and the potato witches'-broom phytoplasma (e.g. strain PWB), which causes potato witches'-broom in North Dakota and Canada (Lee et al., 1998), are classified with strains CP and PWB as members of subgroup 16SrVI-A, sharing about $99.2 \%$ similarity. Strain VR shared only $97.6 \%$ similarity with CP and PWB based on rp gene sequences. Following phylogenetic analysis based on the rp genes, strain VR appeared to represent a separate lineage distinct from strains CP and PWB. Based on RFLP analysis of rp gene sequences, strains VR and PWB (along with strain $\mathrm{CP}$ ) were classified into two rp subgroups, consistent with their differing ecological niches and biological properties. In nature, they are carried by different insect vectors and cause different symptoms in infected plants. Maize bushy stunt (MBS) phytoplasma was classified along with other aster yellows phytoplasma strains (e.g. OAY) as members of subgroup 16SrI-B; this provides another example of a strain with distinct ecology that cannot be differentiated based on the 16S rRNA gene but is readily separated from other members of subgroup 16SrI-B based on RFLP analysis of $\mathrm{rp}$ gene sequences. In the apple proliferation group $(16 \mathrm{SrX})$, three members have been proposed to represent three distinct species, provisionally designated 

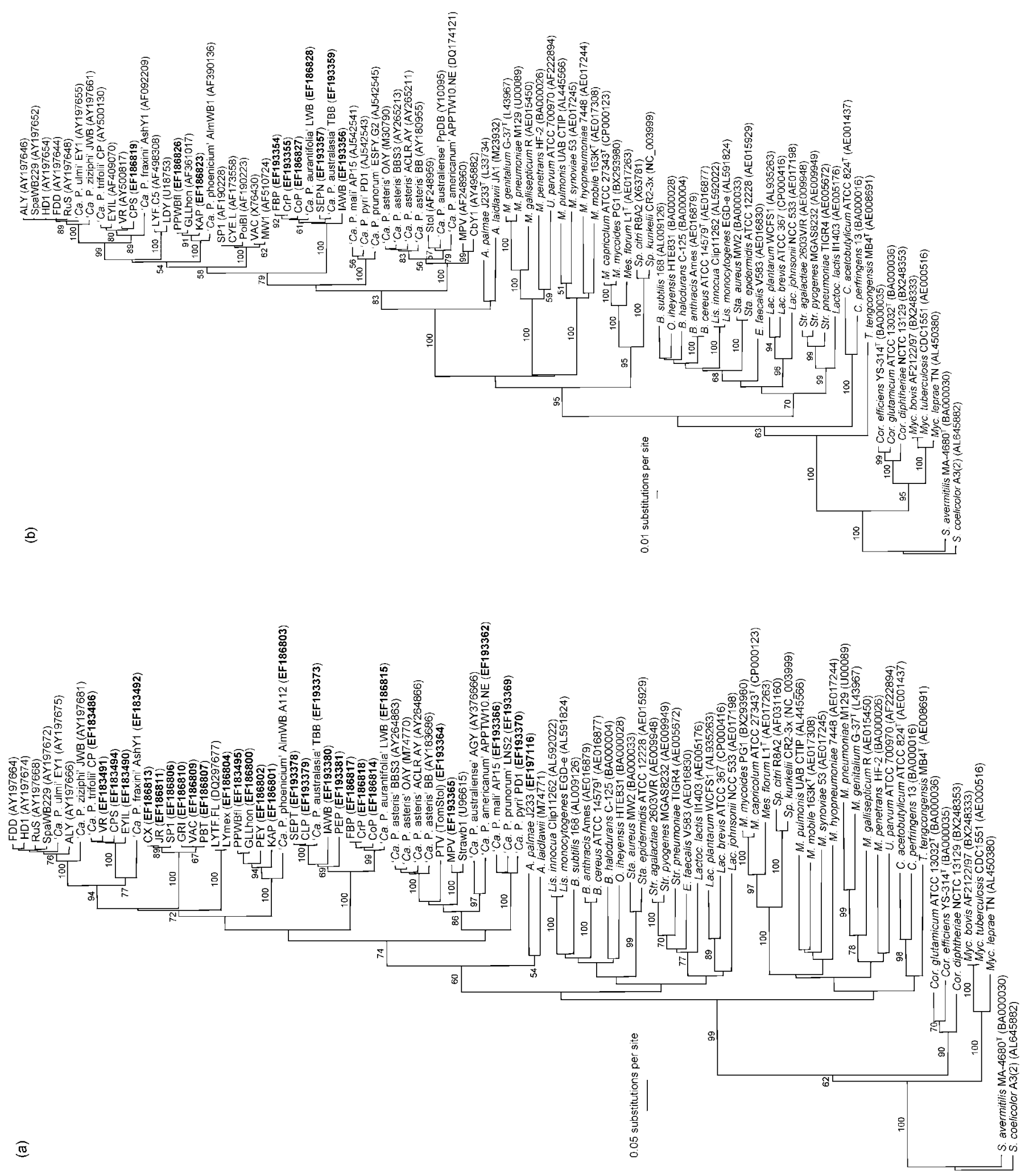

Fig. 2. Phylogenetic trees constructed by parsimony analyses of sequences of rp genes $r p / V(r p / 22)$ and $r p s C$ (rps3) (a) and 16S rRNA genes (b) from members of the class Mollicutes, including 46 (a) and 42 (b) phytoplasma strains. Sequences were aligned with CLUSTAL version 5. The trees were obtained through the neighbour-joining algorithm. Bars, 0.05 (a) and 0.01 (b) substitutions per site. Phytoplasma strain abbreviations are defined in Table 1. Bacterial genus abbreviations and other details are as in Fig. 1. 

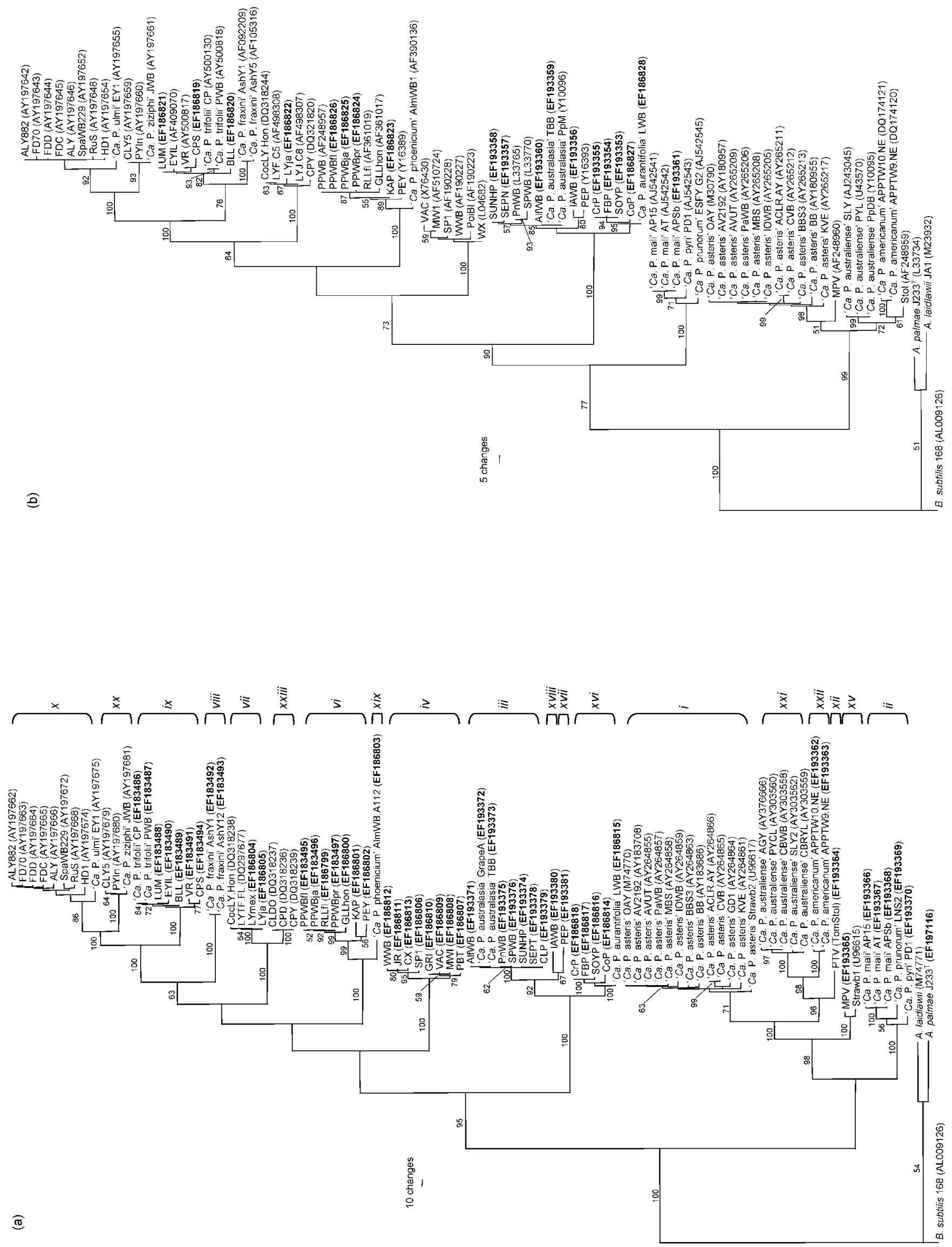
Fig. 3. Phylogenetic trees constructed by parsimony analyses of partial rp operon [covering $r p / V(r p / 22)$ and $r p s C$ ( $r p s 3)$ genes] (a) and 16S rRNA gene (b) sequences from representative phytoplasma strains of different phytoplasma groups. Sequences were aligned with CLUSTAL version 5. B. subtilis 168 was employed as the outgroup. Branch lengths are proportional to the number of inferred character state transformations. Bootstrap values are shown on branches. Bars, 10 (a) and 5 (b) inferred character state changes. Roman numerals shown to the right in (a) represent the phylogenetic subclades identified. Subclades $i-i v$ and $v i-x i i$ were designated to correlate with $16 \mathrm{~S}$ rRNA subclades identified previously. Subclades $x v i-x x i i i$ were identified in this study. Phytoplasma strain abbreviations are defined in Table 1. GenBank accession numbers of sequences obtained in this study are indicated in bold.

'Candidatus Phytoplasma mali', 'Ca. Phytoplasma prunorum' and 'Ca. Phytoplasma pyri', based primarily on their unique biological properties (vector and host specificities). These three strains have an average sequence similarity $>98.7 \%$ based on the $16 \mathrm{~S}$ rRNA gene and are barely differentiated based on RFLP analysis of $16 \mathrm{~S}$ rRNA gene sequences. In contrast, they have an average sequence similarity $<96.5 \%$ based on $r p l V-r p s C$ and can be readily differentiated based on rp gene sequences.

Greater sequence variation in the rp genes has facilitated the design of phytoplasma $16 \mathrm{Sr}$ group-specific primers. In this study, we have designed several semi-universal and group-specific rp primers (Table 2) for amplification of the region extending across $r p s S-r p l V-r p s C$. The amplicons can be used for RFLP analysis or for specific identification of $16 \mathrm{Sr}$ groups or subgroups.

\section{RFLP analysis of rp gene sequences for finer differentiation among strains}

The efficacy of rp gene sequences for finer differentiation among phytoplasma strains in a given $16 \mathrm{Sr}$ group was evaluated by RFLP analysis. Two 16Sr groups, 16SrVI and 16SrX, were selected for analysis. Putative rp gene-based RFLP patterns were generated by using the MapDraw program (Lasergene software; DNASTAR). Based on putative RFLP patterns with four restriction enzymes (AluI, DraI, TaqI and Tsp509I), representative strains CP (subgroup 16SrVI-A), PWB (16SrVI-A), VR (16SrVI-A), EYIL (16SrVIC), LUM (16SrVI), BLL (16SrVI) and CPS (16SrVI) in group 16SrVI were differentiated into six distinct rp subgroups (Supplementary Fig. S2 in IJSEM Online). Strain VR along with strains $\mathrm{CP}$ and PWB have been classified into the same subgroup, 16SrVI-A. Based on rp gene sequences, strain VR represented a separate subgroup of $\mathrm{rp}(\mathrm{VI})$, distinct from strains $\mathrm{CP}$ and $\mathrm{PWB}$, which formed another subgroup of $\mathrm{rp}(\mathrm{VI})$. Based on putative RFLP patterns with two enzymes (AluI and DraI), strains AP15 (subgroup 16SrX-A), AT (16SrX-A), LNS2 (16SrX-B) and PD1 (16SrX-C) were readily differentiated into three distinct $\mathrm{rp}$ subgroups (Supplementary Fig. S3 in IJSEM Online).

\section{Conclusions}

Ribosomal proteins and rRNA are essential components of the ribosome, a ubiquitous cellular organelle. Like the rRNA genes (16S rRNA and 23S rRNA), ribosomal proteins are conserved among bacterial species.
Ribosomal protein genes are among a core of genes in bacteria that share a common history of evolution and carry a strong phylogenetic signal (Daubin et al., 2002; Wolf et al., 2001). These genes are more variable than the $16 \mathrm{~S}$ rRNA gene and serve as a good phylogenetic parameter useful for differentiation and classification of bacterial strains at taxonomic ranks below the genus level.

In the present study, the rp gene-based phylogeny revealed more insights into the phylogenetic relationships among phytoplasma strains. With more variability than the $16 \mathrm{~S}$ rRNA gene, the rp gene sequences provide more phylogenetic markers useful for differentiation of genetically closely related but distinct ecological strains that are not readily separated on the basis of the highly conserved $16 \mathrm{~S}$ rRNA gene. So far, 16S rRNA gene-based RFLP analysis has been applied extensively for differentiation and classification of phytoplasmas. It proves to be very suitable for classification of phytoplasma strains into major 16Sr RFLP groups. However, finer differentiation into subgroups cannot be achieved precisely based on the rather limited number of variable markers present in the 16S rRNA gene. It was proposed that each group represents at least one phytoplasma species. However, there are not sufficient phylogenetic markers to determine the taxonomic rank for each subgroup. The present study and our previous studies indicate that more-variable genes, such as rp or secY, can serve as additional phylogenetic tools for finer differentiation of subgroups within a given $16 \mathrm{Sr}$ group.

\section{REFERENCES}

Abou-Jawdah, Y., Karakashian, A., Sobh, H., Martini, M. \& Lee, I.-M. (2002). An epidemic of almond witches'-broom in Lebanon: classification and phylogenetic relationships of the associated phytoplasma. Plant Dis 86, 477-484.

Arocha, Y., López, M., Piñol, B., Fernández, M., Picornell, B., Almeida, R., Palenzuela, I., Wilson, M. R. \& Jones, P. (2005). 'Candidatus Phytoplasma graminis' and 'Candidatus Phytoplasma caricae', two novel phytoplasmas associated with diseases of sugarcane, weeds and papaya in Cuba. Int J Syst Evol Microbiol 55, 2451-2463.

Bai, X., Zhang, J., Ewing, A., Miller, S. A., Radek, A. J., Shevchenko, D. V., Tsukerman, K., Walunas, T., Lapidus, A. \& other authors (2006). Living with genome instability: the adaptation of phytoplasmas to diverse environments of their insect and plant hosts. J Bacteriol 188, 3682-3696.

Bertaccini, A., Carraro, L., Davies, D., Laimer da Camara Machado, M., Martini, M., Paltrinieri, S. \& Seemüller, E. (2000). Micropropagation of a collection of phytoplasma strains in periwinkle 
and other host plants. In Proceedings of the 13th International Congress of the International Organization for Mycoplasmology, Fukuoka, Japan, 14-19 July 2000, p. 101.

Castresana, J. (2000). Selection of conserved blocks from multiple alignments for their use in phylogenetic analysis. Mol Biol Evol 17, $540-552$.

Daubin, V., Gouy, M. \& Perriere, G. (2002). A phylogenomic approach to bacterial phylogeny: evidence of a core of genes sharing a common history. Genome Res 12, 1080-1090.

Gundersen, D. E., Lee, I.-M., Rehner, S. A., Davis, R. E. \& Kingsbury, D. T. (1994). Phylogeny of mycoplasmalike organisms (phytoplasmas): a basis for their classification. J Bacteriol 176, 5244-5254.

Gundersen, D. E., Lee, I.-M., Schaff, D. A., Harrison, N. A., Chang, C. J., Davis, R. E. \& Kinsbury, D. T. (1996). Genomic diversity and differentiation among phytoplasma strains in $16 \mathrm{~S}$ rRNA group I (aster yellows and related phytoplasmas) and III (X-disease and related phytoplasmas). Int J Syst Bacteriol 46, 64-75.

IRPCM Phytoplasma/Spiroplasma Working Team - Phytoplasma Taxonomy Group (2004). 'Candidatus Phytoplasma', a taxon for the wall-less, non-helical prokaryotes that colonize plant phloem and insects. Int J Syst Evol Microbiol 54, 1243-1255.

Jacobs, K. A., Lee, I.-M., Griffiths, H. M., Miller, F. D., Jr \& Bottner, K. D. (2003). A new member of the clover proliferation phytoplasmas group (16SrVI) associated with elm yellows in Illinois. Plant Dis 87, 241-246.

Jung, H. Y., Sawayanagi, T., Kakizawa, S., Nishigawa, H., Miyata, S., Oshima, K., Ugaki, M., Lee, J. T., Hibi, T. \& Namba, S. (2002). 'Candidatus Phytoplasma castaneae', a novel phytoplasma taxon associated with chestnut witches' broom disease. Int J Syst Evol Microbiol 52, 1543-1549.

Lee, I.-M., Davis, R. E., Sinclair, W. A., DeWitt, N. D. \& Conti, M. (1993a). Genetic relatedness of mycoplasmalike organisms detected in Ulmus spp. in the United States and Italy by means of DNA probes and polymerase chain reactions. Phytopathology 83, 829-833.

Lee, I.-M., Hammond, R. W., Davis, R. E. \& Gundersen, D. E. (1993b). Universal amplification and analysis of pathogen $16 \mathrm{~S}$ rDNA for classification and identification of mycoplasmalike organisms. Phytopathology 83, 834-842.

Lee, I.-M., Gundersen-Rindal, D. E., Davis, R. E. \& Bartoszyk, I. M. (1998). Revised classification scheme of phytoplasmas based on RFLP analyses of $16 \mathrm{~S}$ rRNA and ribosomal protein gene sequences. Int J Syst Bacteriol 48, 1153-1169.

Lee, I.-M., Davis, R. E. \& Gundersen-Rindal, D. E. (2000). Phytoplasma: phytopathogenic mollicutes. Annu Rev Microbiol 54, 221-255.

Lee, I.-M., Martini, M., Bottner, K. D., Dane, R. A., Black, M. C. \& Troxclair, N. (2003). Ecological implications from a molecular analysis of phytoplasmas involved in an aster yellows epidemic in various crops in Texas. Phytopathology 93, 1368-1377.

Lee, I.-M., Martini, M., Marcone, C. \& Zhu, S. F. (2004a). Classification of phytoplasma strains in the elm yellows group $(16 \mathrm{SrV})$ and proposition of 'Candidatus Phytoplasma ulmi' for the phytoplasma associated with elm yellows. Int J Syst Evol Microbiol 54, 337-347.

Lee, I.-M., Gundersen, D. E., Davis, R. E., Bottner, K. D., Marcone, C. \& Seemüller, E. (2004b). 'Candidatus Phytoplasma asteris', a novel phytoplasma taxon associated with aster yellows and related diseases. Int J Syst Evol Microbiol 54, 1037-1048.

Lee, I.-M., Bottner, K. D., Munyaneza, J. E., Secor, G. A. \& Gudmestad, N. C. (2004c). Clover proliferation group (16SrVI) subgroup A (16SrVI-A) phytoplasma is a probable causal agent of potato purple top disease in Washington and Oregon. Plant Dis 88, 429.

Lee, I.-M., Zhao, Y. \& Bottner, K. D. (2006a). SecY gene sequence analysis for finer differentiation of diverse strains in the aster yellows phytoplasma group. Mol Cell Probes 20, 87-91.
Lee, I.-M., Bottner, K. D., Secor, G. \& Rivera-Varas, V. (2006b). 'Candidatus Phytoplasma americanum', a phytoplasma associated with a potato purple top wilt disease complex. Int J Syst Evol Microbiol 56, 1593-1597.

Lim, P. O. \& Sears, B. B. (1992). Evolutionary relationships of a plantpathogenic mycoplasmalike organism and Acholeplasma laidlawii deduced from two ribosomal protein gene sequences. J Bacteriol 174, 2606-2611.

Marcone, C., Ragozzino, A. \& Seemüller, E. (1997a). Detection and identification of phytoplasmas in yellows-diseased weeds in Italy. Plant Pathol 46, 530-537.

Marcone, C., Ragozzino, A. \& Seemüller, E. (1997b). Identification and characterization of the phytoplasma associated with elm yellows in southern Italy and its relatedness to other phytoplasmas of the elm yellows group. Eur J For Pathol 27, 45-54.

Marcone, C., Ragozzino, A. \& Seemüller, E. (1997c). Detection and identification of phytoplasmas infecting vegetable, ornamental and forage crops in southern Italy. J Plant Pathol 79, 211-217.

Martini, M., Botti, S., Marcone, C., Marzachi, C., Casati, P., Bianco, P. A., Benedetti, R. \& Bertaccini, A. (2002). Genetic variability among Flavescence dorée phytoplasmas from different origins in Italy and France. Mol Cell Probes 16, 197-208.

Miyata, S., Furuki, K., Sawayanagi, T., Oshima, K., Kuboyama, T., Tsuchizaki, T., Ugaki, M. \& Namba, S. (2002a). Gene arrangement and sequence of str operon of phytoplasma resemble those of Bacillus more than those of Mycoplasma. J Gen Plant Pathol 68, 62-67.

Miyata, S., Furuki, K., Oshima, K., Sawayanagi, T., Nishigawa, H., Kakizawa, S., Jung, H., Ugaki, M. \& Namba, S. (2002b). Complete nucleotide sequence of the S10-spc operon of phytoplasma: gene organization and genetic code resemble those of Bacillus subtilis. DNA Cell Biol 21, 527-534.

Montano, H. G., Davis, R. E., Dally, E. L., Hogenhout, S., Pimentel, P. \& Brioso, P. S. T. (2001). 'Candidatus Phytoplasma brasiliense', a new phytoplasma taxon associated with hibiscus witches'-broom disease. Int J Syst Evol Microbiol 51, 1109-1118.

Nei, M. \& Kumar, S. (2000). Molecular Evolution and Phylogenetics. New York: Oxford University Press.

Oshima, K., Kakizawa, S., Nishigawa, H., Jung, H., Wei, W., Suzuki, S., Arashida, R., Nakata, D., Miyata, S. \& other authors (2004). Reductive evolution suggested from the complete genome sequence of a plantpathogenic phytoplasma. Nat Genet 36, 27-29.

Prince, J. P., Davis, R. E., Wolf, T. K., Lee, I.-M., Mogen, B. D., Dally, E. L., Bertaccini, A., Credi, R. \& Barba, M. (1993). Molecular detection of diverse mycoplasmalike organisms (MLOs) associated with grapevine yellows and their classification with aster yellows, X-disease, and elm yellows MLOs. Phytopathology 83, 1130-1137.

Razin, S., Yogev, D. \& Naot, Y. (1998). Molecular biology and pathology of mycoplasmas. Microbiol Mol Biol Rev 62, 1094-1156.

Schneider, B., Seemüller, E., Smart, C. D. \& Kirkpatrick, B. C. (1995). Phylogenetic classification of plant pathogenic mycoplasmalike organisms or phytoplasmas. In Molecular and Diagnostic Procedures in Mycoplasmology, vol. 1, pp. 369-380. Edited by R. Razin \& J. G. Tully. San Diego: Academic Press.

Schneider, B., Marcone, C., Kampmann, M., Ragozzino, A., Lederer, W., Cousin, M. T. \& Seemüller, E. (1997). Characterization and classification of phytoplasmas from wild and cultivated plants by RFLP and sequence analysis of ribosomal DNA. Eur J Plant Pathol 103, 675-686.

Schneider, B., Torres, E., Martín, M. P., Schröder, M., Behnke, H.-D. \& Seemüller, E. (2005). 'Candidatus Phytoplasma pini', a novel taxon from Pinus silvestris and Pinus halepensis. Int J Syst Evol Microbiol 55, 303-307. 
Seemüller, E., Schneider, B., Mäurer, R., Ahrens, U., Daire, X., Kison, H., Lorenz, K. H., Firrao, G., Avinent, L. \& other authors (1994). Phylogenetic classification of phytopathogenic mollicutes by sequence analysis of $16 \mathrm{~S}$ ribosomal DNA. Int J Syst Bacteriol 44, 440-446.

Seemüller, E., Marcone, C., Lauer, U., Ragozzino, A. \& Göschl, M. (1998). Current status of molecular classification of the phytoplasmas. J Plant Pathol 80, 3-26.

Swofford, D. L. (1998). PAUP*: phylogenetic analysis using parsimony ( ${ }^{\star}$ and other methods), version 4 . Sunderland, MA: Sinauer Associates.
Valiunas, D., Staniulis, J. \& Davis, R. E. (2006). 'Candidatus Phytoplasma fragariae', a novel phytoplasma taxon discovered in yellows diseased strawberry, Fragaria $\times$ ananassa. Int $J$ Syst Evol Microbiol 56, 277-281.

Wolf, Y. I., Rogozin, I. B., Grishin, N. V., Tatusov, R. L. \& Koonin, E. V. (2001). Genome trees constructed using five different approaches suggest new major bacterial clades. BMC Evol Biol 1, 8.

Zhao, Y., Davis, R. E. \& Lee, I.-M. (2005). Phylogenetic positions of 'Candidatus Phytoplasma asteris' and Spiroplasma kunkelii as inferred from multiple sets of concatenated core housekeeping proteins. Int $J$ Syst Evol Microbiol 55, 2131-2141. 